\begin{tabular}{|l|r|}
\hline Gobal Insigint Journal & Vol 02, No. 01 \\
April-September 2017 \\
ISSN 2541-318X
\end{tabular}

\title{
Kebangkitan Ekonomi China Dan Pengaruhnya Terhadap Beberapa Negara Di Kawasan Asia
}

\author{
Bambang Santoso \\ Universitas 17 Agustus 1945 Jakarta
}

\begin{abstract}
ABSTRAK
Penelitian ini bertujuan untuk mengetahui hal-hal yang mendasari kebangkitan ekonomi negara China. Dewasa ini China telah dikenal luas sebagai raksasa ekonomi di asia dalam perekonomian dunia. Dengan memainkan berbagai peran, sebagai produsen, pemasok, pesaing, pembaharu dan penyedia sumber daya manusia yang handal, China akan mendominasi perekonomian dunia. Menjadi pemain yang tangguh dalam penekanan biaya produksi, peningkatan teknologi dan jasa, serta memiliki ketahanan ekonomi yang kuat dalam memajukan negara.

Metode penulisan yang digunakan adalah tipe penulisan deskriptif dengan penelitian kualitatif. Dalam penulisan ini penulis menggunakan data sekunder yang diperoleh dari sejumlah literatur dan dituliskan dengan menggunakan teknik penulisan deduktif.

Penelitian ini menunjukkan bahwa perkembangan ekonomi yang dicapai oleh China tidak lepas dari berbagai aspek yakni, strategi pembangunan berjangka dan mitra dagang yang dijalin dengan dunia internasional. Strategi pembangunan berjangka yang diterapkan oleh China sangat mengedepankan zona-zona industrinya. Hal ini membuat perkembangan perekonomian China menjadi pusat perhatian dunia.
\end{abstract}

Kata Kunci: Kebangkitan Ekonomi China, Gaige Kaifang, Konsep Pembangunan Ilmiah

\section{ABSTRACT}

This study aims to determine the things that underlie the country's economic rise of China. Nowadays China is widely regarded as an economic giant in Asia in the world economy. By playing a variety of roles, as a manufacturer, supplier, competitor, innovator and provider of qualified human resources, China will dominate the world economy. Be a formidable player in the production cost reduction, improved technology and services, as well as having a strong economic resilience in developing countries. 


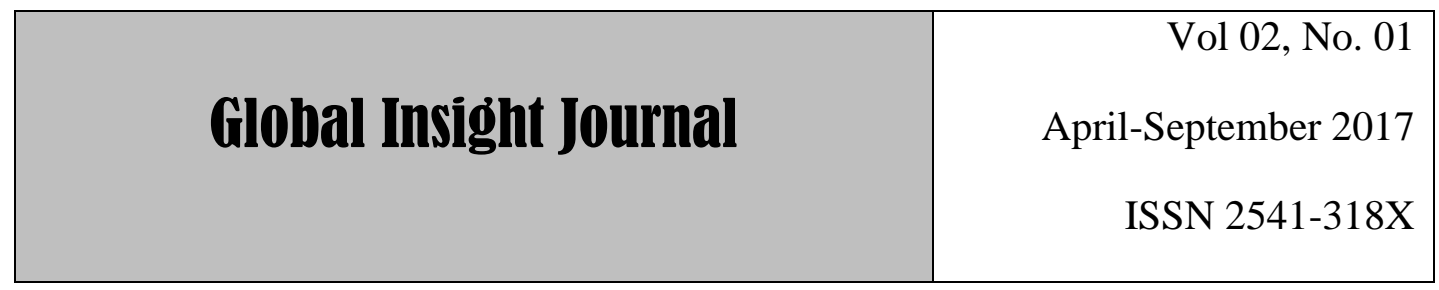

The method used is the type of writing descriptive qualitative research. In this paper the author uses secondary data obtained from a number of literature and writing written using deductive techniques.

This study suggests that the economic growth achieved by China can not be separated from the various aspects of the development strategy and futures trading partners are woven with the international community. Term development strategy adopted by China is promoting its industrial zones. This makes the development of the Chinese economy into the world limelight.

Keywords: Evocation Economics of China, Gaige Kaifang, Scientific Development Concept

\section{PENDAHULAN}

\section{Latar Belakang}

Republik Rakyat China (RRC) berada di kawasan Asia, dengan luas wilayah yang besar mencakup sebagian besar luas daratan Asia dan jumlah penduduk terbanyak di dunia. Akhir-akhir ini begitu menarik perhatian dunia Internasional karena perkembangan perekonomiannya yang melesat naik mengejar ketertinggalannya dari negara-negara lainnya. China kini diakui oleh dunia internasional sebagai salah satu kekuatan ekonomi adidaya di dunia. Negara komunis yang dahulu terpuruk, kini mencapai sukses besar.

Kemajuan yang dicapai ini tidak terlepas dari adanya transformasi dan pembukaan diri yang dilakukan China. China kini tidak menutup diri, keputusan untuk bergabung dengan ekonomi dunia adalah suatu pilihan yang baik bagi kepentingan nasional China. Semua potensi yang ada dimanfaatkan secara maksimal baik itu sumber daya alam ataupun sumber daya manusia, juga didukung strategi dan kebijakan yang terencana oleh pemerintahnya membuat China secara bertahap menjadi raksasa ekonomi baru di kawasan Asia.

Pembukaan diri China, berawal saat Deng Xiaoping mengambil langkah perubahan pertama dan penting bagi perjalanan China menuju ekonomi pasar. Deng 


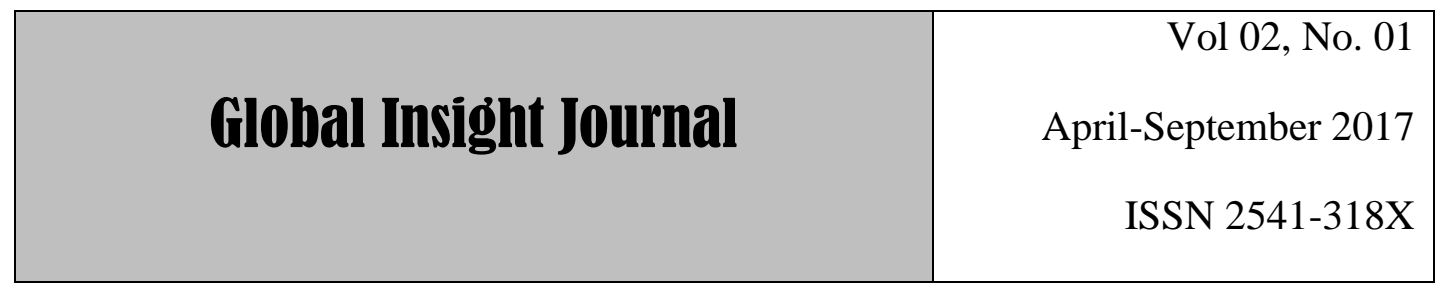

Xiaoping secara bertahap mengubah sistem ekonomi nasional dan melakukan berbagai inovasi dengan melakukan reformasi-reformasi yang membawa China menjadi kekuatan ekonomi yang besar.

Reformasi Deng Xiaoping diawali pada bidang pertanian, yang hingga saat ini pertanian masih menjadi tempat kerja $40 \%$ rakyat China. ${ }^{1}$ Deng Xiaoping memilih memulai pembangunannya dari pedesaan. Lahan kelompok petani dibagi-bagikan kepada masing-masing kepala rumah tangga dan para petani mulai diupah setiap akhir tahun berdasarkan seberapa banyak mereka menanam di lahan mereka.

Sukses dengan reformasi pertaniannya, Deng Xiaoping melangkah pada reformasi industri. Dengan menetapkan strategi membangun zona-zona ekonomi khusus, wilayah-wilayah terbatas, tempat dimana pemerintah tidak memberlakukan undang-undang antibisnisnya dan kemudian diganti dengan pajak yang rendah dan aturan usaha yang mempermudah pabrik-pabrik yang memproduksi barang-barang yang akan dijual ke luar negeri.

Begitu pembangunan zona-zona ekonomi berkembang, China berusaha terus mengundang perusahaan-persahaan asing untuk mendirikan pabrik-pabrik agar dapat mempekerjakan ribuan pekerja China. Pemerintah mengubah lahan pertanian menjadi lokasi industri yang luas dirancang untuk menampung pabrik-pabrik tersebut. Mereka menawarkan kebebasan pajak dan intensif lainnya, serta memasang jaringan telepon dan infrastruktur TI. ${ }^{2}$

Kebijakan pemerintah China dengan membebaskan pajak dan intensif lainnya memberikan hasil. Saat ini, pabrik-pabrik dan investasi lainnya senilai ratusan miliar dolar telah mendatangi China. Jauh diatas tahun 2006 yang investasi asing hanya

\footnotetext{
${ }^{1}$ John, Naisbitt. 2010. China's Megatrends. Jakarta: Gramedia, hal. 8

${ }^{2}$ Robyn, Meredith. 2010. Menjadi Raksasa Dunia. Bandung: Nuansa, hal. 18
} 


\begin{tabular}{|l|r|}
\hline Global Insigint Journal & Vol 02, No. 01 \\
April-September 2017 \\
ISSN 2541-318X
\end{tabular}

mencapai 69 milliar dollar. Investasi asing ini kebanyakan berlokasi di Beijing atau Shanghai dan ditempat lainnya sepanjang pesisisir pantai China. ${ }^{3}$

Pemerintah China menarik investor asing juga untuk tujuan modernisasi. Pemerintah menuntut perusahaan-perusahaan asing tersebut untuk menggunakan, dan mengajari para pekerja China cara menggunakan, teknik-teknik terbaru mereka, membanjiri negara yang ketinggalan teknologi ini dengan pengetahuan dan memacu revolusi industri masa depan yang cepat. ${ }^{4}$

Pada bidang pendidikan, langkah China yang mengundangkan Wajib Belajar di tahun 1986 dengan program pendidikan dasar sembilan tahun, telah membawa perubahan meningkatnya persentase melek huruf menjadi 80 persen di tahun 1990an. Di akhir tahun 1990-an, China hanya mengalokasikan anggaran Resorce and Development kurang dari $1 \%$ dari total GDP, namun saat ini anggaran telah meningkat menjadi $1,5 \%$ dan direncanakan akan terus meningkat hingga mencapai angka 2,5\% di tahun 2020. Hasilnya inovasi ilmu pengetahuan oleh para saintis China telah meningkatkan aplikasi paten sebesar lebih dari 130.000 pada tahun 2004.

Hasil dari kebijakan pemerintah tersebut telah dirasakan oleh rakyat RRC saat ini. Banyak produk-produk industri dan teknologi China sebagai akibat dari transfer teknologi mulai beredar di pasaran. Hal ini membuat industri teknologinya berkembang sangat pesat, bahkan barang-barang hasil produksinya tidak hanya beredar dalam pasar domestik tapi sudah mengglobal.

Suksesnya China melakukan industrialisasi membawa efek dramatis dalam penurunan angka kemiskinan di China. Misalnya pada 1985 tingkat kemiskinan di China mencapai $65 \%$ dan pada tahun 2010 telah turun hingga mencapai 7\%. China berhasil memerangi kemiskinan di daerah basis kemiskinan yakni di daerah pedesaan

\footnotetext{
${ }^{3}$ Ibid, hal. 24

${ }^{4}$ Ibid, hal. 25
} 


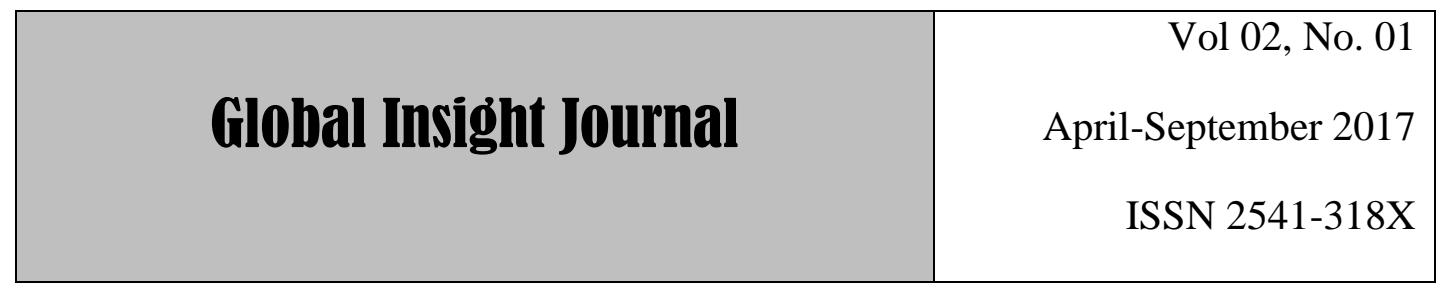

seperti yang dilakukan pada reformasi pertamanya. Hal ini tidak terlepas dari semakin berkembangnya industri manufaktur yang sekitar $50 \%$ dari keuntungan didedikasikan untuk rakyat.

China dalam proses tranformasinya mengejutkan negara-negara barat. Negara ini menjelma menjadi sumber tenaga kerja, mitra, pelanggan dan pesaing sehingga banyak perusahaan-perusahaan asing yang tertarik untuk berinvestasi dan melakukan bisnis. China kini terus bergerak maju mengejar ambisinya untuk menjadi raksasa ekonomi dunia dalam satu generasi.

Ambisi China untuk menjadi raksasa ekonomi dunia bukan tidak mungkin dapat dicapai. Namun, untuk mencapai hal tersebut bukan merupakan hal mudah, dibutuhkan rencana-rencana atau strategi-strategi pembangunan serta pembangunan yang terus berkelanjutan. Selain daripada itu diperlukan juga menjalin kerjasama-kerjasama internasional yang akan menopang pertumbuhan perekonomian masing-masing Negara.

Berdasarkan pemikiran di atas, maka penulis merumuskan bentuk pertanyaan penelitian, sebagai berikut :

1. Faktor-faktor apa yang mendasari kebangkitan ekonomi China?

2. Bagaimana strategi pemerintah China dalam membangkitkan perekonomiannya?

3. Bagaimana pengaruh kebangkitan ekonomi China terhadap beberapa negara di kawasan Asia?

\section{Kerangka Teori}

1. Teori Pertumbuhan-Pembangunan Ekonomi

Awalnya pembangunan ekonomi dimaknai sebagai usaha meningkatkan pendapatan per kapita, atau populer disebut strategi pertumbuhan ekonomi. Peningkatan pendapatan per kapita dihadapkan pada masalah-masalah seperti 


\section{Global Insight Journal}

Vol 02, No. 01

April-September 2017

ISSN 2541-318X

pengangguran, kemiskinan, dan ketimpangan distribusi pendapatan yang dihadapi untuk dapat dihilangkan.

Namun dalam perkembangannya pemikiran itu dikoreksi, dengan pendekatan yang berbeda. Rentang penekanan pada modal sumberdaya alam, modal kapital, modal sumberdaya manusia, modal sosial, modal budaya. Teori ekonomi tradisional memberi perhatian utama pada efisiensi, alokasi dan pemanfaatan sumber daya langka dengan cara yang paling hemat serta pertumbuhan optimal dari sumber daya langka tersebut sepanjang waktu guna menghasilkan produk dan jasa yang cakupannya semakin luas. Pandangan yang juga disebut sebagai teori ekonomi klasik atau neo-klasik ini sampai sekarang masih banyak dianut oleh berbagai negara.

Semakin banyak negara yang percaya bahwa perekonomian akan menjadi lebih baik, tumbuh pesat bila memiliki beberapa persyaratan seperti: tersedianya kapital yang mencukupi di pasar modal; adanya kedaulatan untuk memilih (adanya persaingan bisnis) bagi konsumen sehingga mengarah pada terbentuknya mekanisme penyesuaian harga secara otomatis; keputusan transaksi ekonomi didasarkan pada analisis marginal (rasio pertambahan input dibanding output, rasio keuntungan dan perhitungan utilitas); dan keseimbangan luaran (outcome) dalam semua produk dan pasar sumber daya ekonomi. Semua persyaratan tersebut mengindikasikan adanya rasionalitas dalam keputusan ekonomi yang sepenuhnya materialistik, individualistik, berorientasi pada kepentingan diri sendiri.

Dalam perkembangannya, ada masa ketika terjadi banyak kasus yang menunjukkan ekonomi neoklasik tidak dapat diterapkan secara mandiri. Ia memerlukan dukungan dan intervensi dari institusi lain (sosial dan politik) agar terus menjadi primadona model pembangunan ekonomi. Interaksi ekonomi dan praktik politik inilah yang kemudian mewarnai aktivitas ekonomi-politik di belahan 


\begin{tabular}{|l|r|}
\hline Global Insigint Journal & Vol 02, No. 01 \\
April-September 2017 \\
ISSN 2541-318X
\end{tabular}

bumi ini dalam beberapa dekade terakhir, termasuk ketika ekonomi kapitalis berhasil meruntuhkan kejayaan rejim ekonomi terpusat di negara-negara sosialiskomunis. Runtuhnya pesaing kapitalis, dan mulai maraknya negara-negara eks sosialis-komunis mengadopsi ekonomi kapital, menjadikan teori ekonomi neoklasik kembali ke posisi puncak.

2. Teori Kepentingan Nasional

Kepentingan Nasional (National Interest) adalah tujuan-tujuan yang ingin dicapai sehubungan dengan kebutuhan bangsa/negara atau sehubungan dengan hal yang dicita-citakan. Dalam hal ini kepentingan nasional yang relatif tetap dan sama diantara semua negara/bangsa adalah keamanan (mencakup kelangsungan hidup rakyatnya dan kebutuhan wilayah) serta kesejahteraan. Kedua hal pokok ini yaitu keamanan (Security) dari kesejahteraan (Prosperity). Kepentingan nasional diidentikan dengan dengan "tujuan nasional". Contohnya kepentingan pembangunan ekonomi, kepentingan pengembangan dan peningkatan kualitas Sumber Daya Manusia (SDM) atau kepentingan mengundang investasi asing untuk mempercepat laju industrialisasi.

Kepentingan nasional sering dijadikan tolak ukur atau kriteria pokok bagi para pengambil keputusan (decision makers) masing-masing negara sebelum merumuskan dan menetapkan sikap atau tindakan. Bahkan setiap langkah kebijakan luar negeri (Foreign Policy) perlu dilandaskan kepada kepentingan nasional dan diarahkan untuk mencapai serta melindungi apa yang dikategorikan atau ditetapkan sebagai "Kepentingan Nasional". 5

Menurut Hans J.Morgenthau didalam "The Concept of Interest defined in Terms of power", Konsep Kepentingan Nasional yang didefiniskan dalam istilah "power"

\footnotetext{
${ }^{5}$ T.May Rudy, 2002, Studi Strategis Dalam Transformasi Sistem Internasional Pasca Perang Dingin, Bandung: Refika Aditama, hal. 116
} 


\begin{tabular}{|l|r|}
\hline Global Insigint Journal & Vol 02, No. 01 \\
April-September 2017 \\
ISSN 2541-318X
\end{tabular}

menurut Morgenthau berada diantara nalar, akal atau "reason" yang berusaha untuk memahami politik internasional dengan fakta-fakta yang harus dimengerti dan dipahami. Dengan kata lain, power merupakan instrumen penting untuk mencapai kepentingan nasional. ${ }^{6}$

Konsep kepentingan nasional juga mempunyai indikasi dimana negara atau state berperan sebagai aktor utama di dalam formulasi politik yang merdeka berdaulat. Selanjutnya didalam mekanisme interaksinya masing-masing negara atau aktor berupaya untuk mengejar kepentingan nasionalnya. Kepentingan inilah yang Morgenthau berpendapat bahwa strategi diplomasi berdasarkan kepada kepentingan nasional. Kepentingan nasional tersebut digunakan untuk mengejar "power" yang bisa digunakan untuk membentuk dan mempertahankan pengendalian suatu negara atas negara lain. Menurut Morgenthau, dengan memiliki power maka suatu negara dapat mengadili negara lain seperti mengadili negara sendiri dan kemudian dapat meningkatkan kepentingan negara yang memiliki "power.

\section{Teori Ekonomi Politik}

Aliran Neoliberalisme Mazhab Freiburg/Ordo Liberal

Mazhab Freiburg/Ordo Liberal mengembangkan gagasan ekonomi politik yang beraliran liberal yang sudah mengakomodir kritik yang dilancarkan oleh para pakar sosialis/marxis terhadap liberalisme klasik. Dalam bentuk konsepsi "ekonomi pasar sosialis" (Social Market Economy), sebuah bentuk sistem ekonomi campuran tetap membutuhkan peran pemerintah untuk menghindari adanya konsentrasi kekuasaan ekonomi oleh individu maupun sekelompok orang serta untuk menjaga keadilan dan kesejahteraan sosial. Sebagai suatu sistem, ekonomi pasar sosialis sudah berusaha

\footnotetext{
${ }^{6}$ Mohtar Masoed, 1990, ILMU HUBUNGAN INTERNASIONAL; Disiplin dan Metodelogi, Jakarta: Pustaka LP3ES Indonesia, hal. 139-140
} 


\begin{tabular}{|l|r|}
\hline Global Insigint Journal & Vol 02, No. 01 \\
April-September 2017 \\
ISSN 2541-318X
\end{tabular}

memerangi kekuasaan sektor publik maupun privat atas pasar sekaligus memerangi pasar bebas tanpa aturan maupun kecenderungan perencanaan yang bersifat otoriter.

Para pakar penggagas ordo liberal tidak percaya bahwa pasar dan persaingan atau kompetisi sebagai sesuatu yang alami dan berjalan menurut hukum universal. Menurut mereka pasar hanya salah satu model dari hubungan sosial yang merupakan bentukan manusia. Mereka percaya bahwa kinerja pasar memerlukan tindakan politik, dalam hal ini pemerintah harus menjalankan fungsinya menciptakan iklim yang kondusif sehingga pasar dapat beroperasi secara adil dalam suasana yang kompetitif. ${ }^{7}$

\section{Teori Kebijakan Luar Negeri}

Dalam membahas kebijakan luar negeri, pengertian dasar yang harus diketahui yaitu kebijakan luar negeri itu pada dasarnya merupakan "action theory", atau kebijaksanaan suatu negara yang ditujukan ke negara lain untuk mencapai suatu kepentingan tertentu. Secara umum, politik luar negeri (foreign policy) merupakan suatu perangkat formula nilai, sikap, arah serta sasaran untuk mempertahankan, mengamankan, dan memajukan kepentingan nasional di dalam percaturan dunia internasional.

Kebijakan luar negeri merupakan suatu strategi dalam menghadapi unit politik internasional lainnya yang dibuat oleh pembuat keputusan negara (decision maker) dalam rangka mencapai tujuan spesifik nasional dalam terminologi national interest.

Mark R. Amstutz mendefinisikan kebijakan luar negeri sebagai "explicit and implicit actions of governmental officials designed to promote national interest beyond a country's territorial boundaries". Terdapat tiga fokus utama dalam

\footnotetext{
${ }^{7}$ Drs.Deliarnov, M.Sc, 2006, Mencakup Berbagai Teori dan Konsep yang Komprehensif; EKONOMI POLITIK, Jakarta: Erlangga, hal. 162-163
} 


\section{Global Insight Journal}

Vol 02, No. 01

April-September 2017

ISSN 2541-318X

definisi ini yaitu; tindakan atau kebijakan pemerintah, pencapaian kepentingan nasional dan jangkauan kebijakan luar negeri yang melampaui batas kewilayahan suatu negara. Dengan demikian setiap kebijakan pemerintah yang memberikan dampak bagi aktor-aktor lain di luar batas wilayahnya secara konseptual merupakan bagian dari pengertian kebijakan luar negeri. Kebijakan luar negeri mencakup dimensi yang luas baik itu dimensi ekonomi, keamanan maupun sosial budaya. ${ }^{8}$

\section{PEMBAHASAN}

\section{A. Faktor-Faktor Yang Mendasari Kebangkitan Ekonomi China}

\section{Arah kebijakan masa kepemimpinan Deng Xiaoping}

Deng Xiaoping memasukkan elemen-elemen modernisasi dalam konstitusinya. Sejak tahun 1978, China mencanangkan program "modernisasi empat" yang merupakan upaya para pemimpin China pasca Mao antara lain untuk mengatasi keterbatasan domestiknya, yakni modernisasi pertanian, industri, ilmu pengetahuan dan teknologi serta militer. Pengembangan ekonomi menjadi prioritas utama, mengingat kelemahan ekonomi merupakan sumber fundamental dari kerentangan nasional. Empat modernisasi itu telah dijadikan sebagai konstitusi partai, sehingga akan tetap dijalankan kendati terjadi pergantian kepemimpinan. ${ }^{9}$

Pada dasarnya pembaharuan ekonomi China berintikan pada reformasi sistem ekonomi dimaksudkan untuk meningkatkan efisien produksi dan alokasi sumber-sumber daya, sementara strategi pertumbuhan diarahkan untuk

\footnotetext{
${ }^{8}$ Aleksius Jemadu, 2008, Politik Global Dalam Teori dan Praktik, Yogyakarta: Graha Ilmu, hal. 65

${ }^{9}$ T.M. Siregar, 2002, Pembangunan Ekonomi Tiongkok; dari fokus pedesaan ke pasar internasional, Jakarta: Pustaka Pena. hal. 64
} 


\begin{tabular}{|l|r|}
\hline Global Insigint Journal & Vol 02, No. 01 \\
April-September 2017 \\
ISSN 2541-318X
\end{tabular}

meningkatkan pendapatan dari ekspor komoditi manufaktur. Deng Xiaoping kemudian melakukan perubahan terhadap hubungan produksi yang kini lebih berorientasi pada produktivitas. Kebijakan yang diambil kini mengutamakan strategi dan taktik yang fleksibel untuk melakukan modernisasi, dengan begitu sifat dari pengembangan ini akan lebih cepat menyesuaikan dan berkelanjutan.

\section{Potensi Ekonomi}

\subsection{Sumber Daya Alam}

Negara China adalah negara yang mempunyai luas wilayah yang sangat besar, meliputi luas wilayah kira-kira 9,6 juta $\mathrm{km}^{2}$ dan 4,7 juta perairan pantai dengan perbatasan darat sepanjang $22.800 \mathrm{~km}$ hampir seperlima daratan dunia atau seperempat Asia. Terdapat beraneka kondisi geologis China menguntungkan bagi terjadinya proses mineralisasi yang telah menciptakan cadangan mineral yang beragam jenis dengan deposit yang besar. China memiliki wilayah hutan seluas 115 juta hektar dan wilayah padang rumput 318,08 juta hektar, wilayah air tawar 22,434 juta dan wilayah perikanan samudra mencakup 818.000 mil laut persegi. Memiliki 24.500 varietas tumbuhan biji sebagian termasuk dalam tumbuhan yang sangat langka. Beragam spesies satwa yang mencapai 420 spesies hewan liar, 1.166 spesies burung, 510 spesies reptil dan ampibi. ${ }^{10}$

\subsection{Tenaga Kerja}

Potensi ekonomi yang lain yang dapat dilihat adalah ketersediaan jumlah tenaga kerja yang begitu besar. Angka tenaga kerja produktif yang ada China selalu stabil dalam beberapa dekade terakhir. Berdasarkan data tahun

${ }^{10}$ Ibid, hal. 21-22 


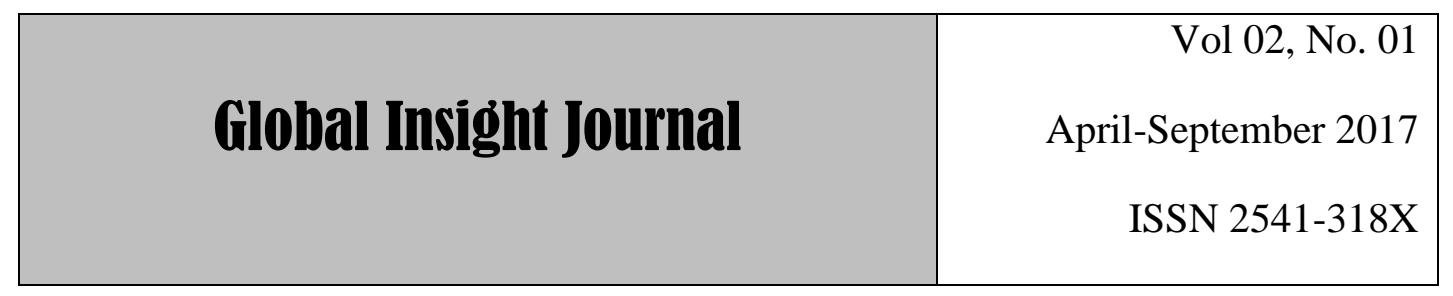

2008 tingkat populasi China mencapai 1.322 miliar jiwa mencakup 39\% populasi Asia dan $40 \%$ populasi Asia Selatan. Hal ini akan sangat berpengaruh dalam upaya mendukung pembangunan berbagai proyek pabrik atau industri manufaktur yang ada China yang dalam perkembangannya terus mengalami pertumbuhan yang sangat pesat. ${ }^{11}$

\subsection{Modal Investasi}

Dari perspektif perusahaan multinasional atau MNC, China adalah "world's factory" sehingga banyak sekali perusahaan-perusahaan dunia yang beroperasi di China. China memiliki peran besar dalam dinamika perekonomian global. China merupakan salah satu tujuan utama untuk Foreign Direct Investement (FDI) global. China secara konsisten menarik lebih dari \$ 50 juta dari investasi luar negeri per tahunnya. Dalam kacamata interdepensi ekonomi, dimana China dianggap sebagai tempat yang strategis bagi para investor asing untuk menanamkan modalnya atau mengirimkan MNCnya ke China. Sedangkan bagi China sendiri keberadaan MNC merupakan suatu keuntungan dalam bidang ekonomi dengan semakin banyaknya FDI yang masuk ke China.

Investasi yang begitu besar dilihat sebagai potensi untuk terus memaksimalkan pembangunan yang ada di China. Hal ini terlihat dari model pembangunan yang terkonsep dituangkan dengan pembangunan infrastruktur yang menunjang perekonomian di berbagai kota besar di China seperti Shanghai, Beijing, Guangzhou, Dalian dan Tianjin telah memiliki menara perkantoran, hotel, villa mewah, jalan tol, terminal kontainer, bandara, pusat

\footnotetext{
${ }^{11}$ Michael Backman, 2008, Asia Future Shock. Jakarta: Ufuk Press. hal. 03
} 


\section{Global Insigint Journal}

Vol 02, No. 01

April-September 2017

ISSN 2541-318X

perbelanjaan, dan taman-taman publik serta berbagai infrastruktur yang akan dibangun dengan kecepatan yang menakjubkan. ${ }^{12}$

\subsection{Pasar}

Salah satu potensi ekonomi yang dimiliki China yang tidak dapat dipungkiri adalah kekuatan pasar. Bertahun-tahun lamanya, pihak-pihak yang sinis melecehkan investor luar negeri yang tergila-gila dengan visi untuk menjual apa saja, mulai dari mobil hingga kosmetik "1 milliar customer China”. Saat ini China berada diantara pasar konsumsi paling penting di dunia. China sudah menjadi customer telepon tanpa kabel terbesar 1 dunia, dengan jumlah customer mencapai 350 juta telepon seluler. ${ }^{13}$

China saat ini juga menjadi pasar mobil terbesar ketiga di dunia dan sedang melaju menjadi pasar terbesar bagi PC, layanan telekomunikasi Broadband, televisi digital, dan masih banyak barang lainnya. Hal ini tidak terlepas dari pesatnya industri manufaktur yang ada di China yang sejalan dengan terus berkembangnya perekonomian yang ada di negara tersebut. Dilengkapi dengan adanya seperangkat institusi pasar yang berfungsi baik, memungkinkan pelaku ekonomi untuk memperbaiki diri dengan berusaha dan bekerja keras sehingga dapat meningkatkan kekayaan untuk diri mereka sendiri serta sekaligus meningkatkan kekayaan masyarakat. Selama periode reformasi pemerintah China terus berusaha memperbaiki institusi pasarnya seperti memperbaiki sistem perbankan dan sistem hukum agar perekonomian berjalan semakin baik. ${ }^{14}$

\footnotetext{
${ }^{12}$ Pamela Yatsko, 2003, New Shanghai; Lika-liku Kelahiran Kembali Kota Legendaris di Cina. Batam: Interaksara. hal. 354.

${ }^{13}$ Pete Engardio, 2008, Chindia. Jakarta: Gramedia Pustaka

${ }^{14}$ Chow, Gregory C, 2010, Memahami Dasyatnya Ekonomi China. Solo: Tiga
} 


\begin{tabular}{|l|r|}
\hline Global Insigint Journal & Vol 02, No. 01 \\
April-September 2017 \\
ISSN 2541-318X
\end{tabular}

3. Potensi Ilmu Pengetahuan dan Teknologi

Menyadari ketertinggalan akan kekurangan tenaga profesional, China kemudian berusaha meningkatkan sains, teknologi, dan pendidikan tinggi dengan begitu mengesankan. Kemajuan tersebut berawal dari mempelajari kemudian berkembang menjadi menemukan dan mengekspor pengetahuan. Di bidang pendidikan tinggi, jumlah guru yang bekerja penuh waktu, dan tetap berjumlah sekitar 400.000 dari 1988 hingga 1998, meningkat menjadi 1.170.000 pada tahun 2007, atau sekitar 13 persen pertahun. Dari 1998 hingga 2007, jumlah mahasiswa pascasarjana yang pergi ke luar negeri untuk belajar meningkat dari 72.508 menjadi 418.612, atau 22 persen pertahun, jumlah mahasiswa yang lulus meningkat dari 47.077 menjadi 311.839, atau 22 persen pertahun. Kebijakan sektor edukasi, dimana China menerapkan wajib belajar, melarang adanya pekerja di usia sekolah dan mengembangkan vocational education untuk memberikan keterampilan kepada masyarakat, sehingga akan tersedia pekerja dengan skill yang tinggi.

4. Potensi Industri

Langkah dan ukuran kebangkitan China sebagai lokomotif usaha manufaktur telah mencengangkan masyarakat internasional dan dunia. Pada akhir tahun 2006, China diperkirakan mengekspor barang bernilai lebih dari 800 milliar USD yang jumlahnya meningkat tiga kali lipat dibandingkan tahun 2002 dan bahkan mencapai 1 trilliun USD pada tahun 2008. Dengan berakhirnya kuota tekstil internasional pada tahun 2005, China mengambil alih separuh dari seluruh garmen yang diimpor Amerika Serikat. Negara ini juga membuat sebagian besar mainan, sepatu, jam tangan, dan alat perkakas dunia. 


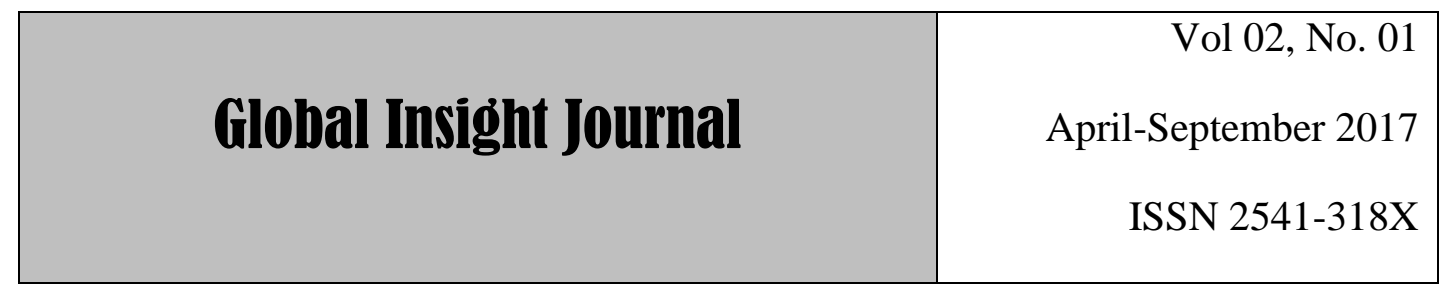

Ide bahwa China akan terus memimpin produk murah sementara manufaktur produk mahal akan tetap selalu berada di negara-negara maju juga sudah tidak tepat lagi. Dari pabrik peralatan yang dikendalikan oleh komputer senilai jutaan dollar sampai router (pengatur data) berjaringan seharga 200.000 USD, produksi sudah dengan cepat bergeser ke China termasuk produksi terhadap produksi sebagian besar pekerjaan rekayasa komponen, material, dan komponennya dengan kata lain China telah mampu melakukan produksi terhadap barang-barang mahal dan berteknologi lainnya yang dulu hanya mampu diproduksi oleh Amerika Serikat dan negara-negara di kawasan eropa lainnya.

\section{B. Strategi Kebangkitan Ekonomi China}

1. Strategi Pembangunan Ekonomi China

China merupakan salah satu negara yang menetapkan strategi pembangunan melalui pendirian zona-zona khusus. Di mana yang dimaksud dengan pendirian zona-zona khusus ini adalah zona-zona tertentu yang didirikan oleh suatu negara di dalam wilayah kedaulatannya yang jenisnya sangat beragam, mulai dari sekedar ditujukan untuk pengolahan ekspor (Export Processing Zone, EPZ) hingga zona yang ditujukan bagi pengembangan teknologi (misalnya Hi-Tech Industrial Park). Namun pada dasarnya, seluruh zona tersebut memiliki kesamaan yakni memberikan perlakuan khusus bagi investor asing untuk berproduksi. Perlakuan khusus yang diberikan dapat berupa pembebasan dari berbagai kewajiban pajak, peniadaan atau pengurangan berbagai hambatan baik berupa tarif maupun non tarif, dan lain sebagainya.

Adapun sebenarnya, tujuan strategi dari pembangunan zona-zona khusus tersebut sangat sesuai untuk meningkatkan keunggulan komparatif suatu negara. Sebab dalam hal ini, meningkatnya investasi asing pada suatu negara dapat 


\section{Global Insight Journal}

Vol 02, No. 01

April-September 2017

ISSN 2541-318X

semakin mengintegrasikan ekonomi negara tersebut dengan sistem ekonomi global dan dengan semakin besarnya share yang dapat diperoleh negara tersebut dalam ekonomi global tentunya akan semakin berkontribusi positif terhadap pertumbuhan ekonomi negara tersebut. ${ }^{15}$

Langkah China dalam membentuk ribuan zona khusus yang jenisya beragam, baik di tingkat nasional maupun daerah, pada dasarnya merupakan strategi yang dipelajari oleh China dari negara-negara lain di Asia Timur, yakni Hongkong (Daerah Administratif Khusus China), Taiwan, Korea Selatan, dan Singapura. Di mana proses pembentukan ribuan zona khusus tersebut dilakukan tidak secara langsung dan serempak melainkan mempertimbangkan aspek gradualitas dan eksperimental yang menjadi ciri khas pembangunan China pasca reformasi tahun 1978.

Kebutuhan China terhadap modal asing merupakan suatu given factor yang memicu pengembangan ZEK, sama seperti negara-negara lainnya. Poin yang menjadi karakter khusus bagi China yang membedakan antara pengembangan ZEK di China dengan negara-negara lainnya adalah menyangkut tiga hal. Pertama yaitu inisiator pengembangan ZEK tidak selalu dari pemerintah pusat dan bahkan pengembangan ZEK untuk pertama kali diusulkan oleh salah satu pemerintah daerah di China yakni pemerintah Provinsi Guangdong. Karakter khusus kedua yang dimiliki oleh China adalah terdapat berbagai variasi ZEK di China yang meliputi Special Economic Zones (SEZs), Pudong New Area, Economic and Technological Development Zones (ETDZs), Bonded Zones, Free Trade Zones (FTZs), Export Processing Zones (EPZz), High Technology Industrial Development Zones (HIDZs), Special Purpose

\footnotetext{
${ }^{15}$ Wiryawan, Bangkit A, 2008, Zona Ekonomi Khusus Strategi China Memanfaatkan Modal Global. Depok: Yayasan CCS. hal. 01
} 


\section{Global Insight Journal}

Vol 02, No. 01

April-September 2017

ISSN 2541-318X

Parks, dan Bonded Economic Cooperative Zones (BECZs), di mana saat ini pemerintah Cina telah mengesahkan 3000 ZEK yang meliputi jenis-jenis di atas. Sementara untuk karakter khusus yang ketiga, China memiliki pola pengembangan ZEK yang gradual. Karakter-karakter khusus tersebutlah yang kemudian membedakan China dengan negara-negara lain yang juga memberlakukan ZEK sehingga dapat dikatakan bahwa hal itu pun pada akhirnya menjadi strategi China dalam menjalankan strateginya mengembangkan ZEK. ${ }^{16}$

Selanjutnya konsep "wawasan ilmiah pembangunan" yang menjadi acuan pedoman yang dianut generasi baru pemerintah pusat pimpinan Hu Jintao. Ada tiga pilar yang coba dicakup oleh konsep "wawasan ilmiah pembangunan" yang dibangun oleh China ini yakni pilar pertama mengutamakan rakyat, poin ini menegaskan segala bentuk proyek pembangunan yang sedang maupun akan dikerjakan harus berorientasi terhadap kepentingan rakyat China itu sendiri dalam hal ini bagaimana dapat mengangkat harkat dan martabat rakyat China melalui peningkatan kualitas perekonomian masyarakatnya.

Pilar yang kedua adalah pembangunan yang seimbang dan berkelanjutan adalah syarat dasar dan mutlak untuk dipenuhi. Artinya, pembangunan tidak hanya berorientasi bagaimana bisa membangun berbagai infrastruktur yang memadai dan modern tetapi juga harus memperhatikan ekologi atau kondisi lingkungan. Pembangunan yang dilakukan tanpa merusak ekologi atau alam. Selain itu bagaimana pembangunan yang dimaksud dapat berkontinuitas atau berkelanjutan dengan adanya pembangunan dalam jangka panjang dengan adanya master-plan yang bersifat matang dalam rangka merekonstruksi China ke arah yang lebih baik.

${ }^{16} \mathrm{Ibid}$, hal. 11 


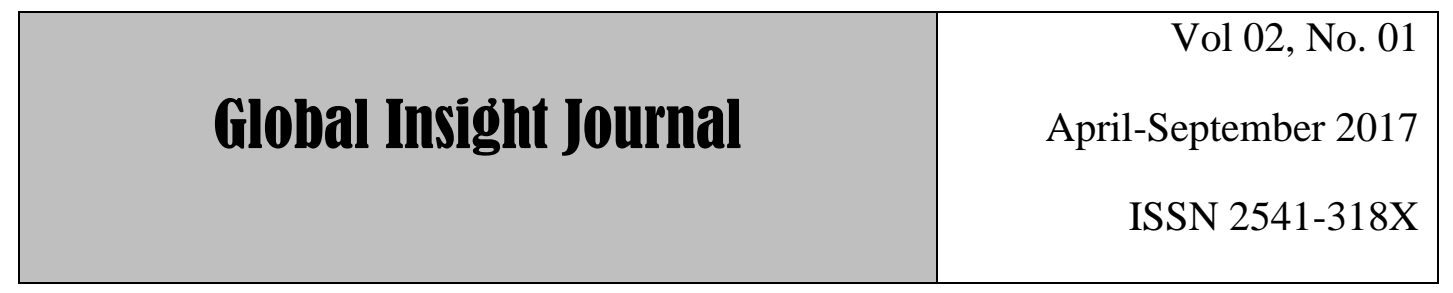

Pilar yang ketiga adalah perencanaan yang mempertimbangkan semua pihak adalah pendekatan yang mendasar. Pilar ini menekankan bagaimana pembangunan ini dapat dirasakan oleh berbagai lapisan masyarakat manfaatnya. Pembangunan yang hanya menguntungkan segelintir orang dalam proses pembangunannya dan tidak dirasakan manfaatnya oleh semua lapisan masyarakat.

Ketiga pilar tersebut jika dirumuskan menjadi "menerapkan pendekatan ilmiah dalam pembangunan yang komperhensif, seimbang, dan berkelanjutan". ${ }^{17}$ Hal ini menuntut China tidak hanya memajukan pembangunan ekonomi, tapi juga pembangunan politik, budaya, sosial, dan ekologi; untuk mengkoordinasi dan memberi perhatian penuh pada semua aspek, wilayah, serta kaitan pembangunan; untuk melestarikan sumber daya alam dan melindungi lingkungan hidup bagi kehidupan yang lebih baik serta ruang pembangunan bagi generasi mendatang; untuk memfokuskan diri pada peningkatan mata pencaharian rakyat dan memajukan keadilan sosial bagi seluruh rakyat China; serta memastikan pembangunan dan hasil dari pembangunan dapat terdistribusi dan dirasakan manfaatnya oleh seluruh rakyat China yang berjumlah sekitar 1,3 milliar orang.

China menyadari kesuksesan pembangunan berkelanjutan tidak hanya berfokus pada sektor perekonomian saja tetapi juga terhadap berbagai sektor lain yang saling mempengaruhi. Sektor lain yang dimaksud adalah bagaimana pemerintah mampu membingkai sektor politik, keamanan, budaya, maupun ekonomi itu sendiri sehingga tercipta iklim investasi yang kondusif guna

\footnotetext{
${ }^{17}$ John Naisbit, Dorris Naisbit, 2010. China's Megatrends, 8 Pilar Masyarakat Baru, Jakarta: Gramedia Pustaka. hal. 82
} 


\section{Global Insigint Journal}

Vol 02, No. 01

April-September 2017

ISSN 2541-318X

berkontribusi terhadap akselerasi pembangunan sehingga terjadi pembangunan yang terus dinamis dan berkelanjutan.

2. Strategi pembangunan pada bidang ilmu pengetahuan, Teknologi dan Industri

Perkembangan ilmu pengetahuan di China juga menunjukkan peningkatan yang cukup berarti. Strategi zonanisasi yang mengarahkan ibukota Beijing dan Tianjin sebagai pusat penelitian dan pengembangan dunia. Daerah Beijing-Tianjin dikenal sebagai koridor IT China, dengan Beijing sebagai pusat penelitian dan pengembangan, dan Tianjin sebagai basis industrialisasi dan produksi. Silicon Valley versi China, Zhongguancun merupakan lokasi bagi hampir 5.000 perusahaan China yang bergerak dalam bidang teknologi mutakhir, termasuk dengan perusahaan bernama besar seperti Lenovo, lebih dari 1.000 perusahaan IT internasional. ${ }^{18}$ Lokasi itu merupakan hasil gabungan ciptaan yang menakjubkan dari orang-orang ber-IQ jenius dan jiwa wirausaha yang tinggi, dengan melibatkan lebih 70 universitas, termasuk universitas Peking dan Universitas Tsinghua, yang dianggap sebagai Harvard dan MIT belahan Asia.

Universitas-universitas itu mendidik para elit sosial dan pemimpin yang telah mengungguli tamatan-tamatan sekolah menengah ke atas lain melalui serangkaian ujian yang ketat yang telah berlangsung sejak murid-murid masuk ke sekolah dasar, dan diseleksi lewat sistem rekruitmen universitas di China yang sangat kompetitif. Sekitar 500.000 peneliti dan personel teknis yang bekerja di Zhongguancum. Sebagian di antaranya dipekerjakan oleh lebih dari 200 institusi penelitian ilmu pengetahuan dan teknologi di Zhongguancum, termasuk organisasi-organisasi dengan reputasi tinggi dalam Akademi Ilmu Pengetahuan China (Chinese Academy of Science) seperti Institut Teknik

\footnotetext{
${ }^{18}$ N Lam Mark, John L. Graham, 2007, China Now, Jakarta: Gramedia. hal. 267
} 


\section{Global Insight Journal}

Vol 02, No. 01

April-September 2017

ISSN 2541-318X

Elektro (Institute of Electrical Enggineering), Institut Elektronika (Institute Electronics), Pusat penelitian dan Pengembangan Microelektronika (Microelectronics $R \& D$ Centre), Institute Semikonduktor (Institute of Semiconductors), Pusat Informasi Jaringan Komputer (Computer Network Information Centre), Institute Perangkat Lunak (Institute of Software), dan Institute Teknologi Komputasi (Institute of Computing Technology). Institutinstitut akademis ini mendirikan dan mengembangkan perusahaan-perusahaan milik mereka sendiri untuk mengindustrialisasikan dan mengkomersialisasikan pencapaian-pencapaian dan hasil-hasil penelitian mereka.

\section{Pengaruh Kebangkitan Ekonomi China Terhadap Beberapa Negara di Kawasan Asia}

Reformasi ekonomi China yang diinisiatifkan oleh Deng Xiaoping pada tahun 70-an telah merubah persepsi dunia luar terhadap China. Sebelumnya hubungan negara luar dengan China hanya berlandaskan ideologi politik. Negara yang mempunyai ideologi yang berlainan dengan China masih belum yakin untuk menjalin hubungan dengan China ketika itu.

Salah satu cara untuk mempererat hubungan satu negara dengan negara lainnya adalah dengan melakukan perdagangan internasional. Perdagangan internasional merupakan salah satu aspek penting dalam perekonomian setiap negara di dunia. Dengan perdagangan internasional, perekonomian akan saling terjalin dan tercipta suatu hubungan ekonomi yang saling mempengaruhi suatu negara dengan negara lain serta lalu lintas barang dan jasa akan membentuk perdagangan antar bangsa. Perdagangan internasional pada saat ini semakin berkembang dengan adanya sistem inovasi teknologi informasi, perdagangan, reformasi politik, transnasionalisasi sistem keuangan, dan investasi. Dan ini bisa menjadi modal yang penting bagi suatu 


\section{Global Insight Journal}

Vol 02, No. 01

April-September 2017

ISSN 2541-318X

negara untuk menarik investor masuk ke dalam negerinya untuk menanam investasi di negaranya. Apalagi didukung dengan situasi politik yang kondusif dan lingkungan bisnis yang kompetitif di dalam negara tersebut, maka bukan tidak mungkin perkembangan ekonomi negara tersebut akan tumbuh semakin cepat.

China mulai mempromosikan globalisasi ekonominya, terlihat jelas arah kebijakan luar negerinya dimana China menginginkan keadaan yang kondusif bagi pertumbuhan ekonominya dengan membangun berbagai kerjasama ekonomi baik bilateral maupun tingkat regional. Bagaimanapun reformasi ekonomi China telah menarik perhatian negara luar untuk menjalin hubungan ekonomi dengan China dengan menilai kepada potensi pertumbuhan ekonomi China. Negara luar memperkirakan dengan menjalin hubungan ekonomi yang kuat dengan China akan memberikan keunggulan kompetitif (competitive advantage) ditambah dengan pendirian bahwa hubungan ekonomi yang baik dengan sendirinya akan membantu memperkuat hubungan politik.

Kebangkitan ekonomi China memberikan pengaruh yang cukup signifikan kepada beberapa negara-negara di kawasan Asia. Kemajuan pesat pembangunan ekonomi China akan membuka lebih banyak peluang bagi kerja sama bilateral antara China dan negara-negara Asia dalam hubungan ekonomi bahkan menjadi mitra dagang yang penting, tercermin dari meningkatnya nilai perdagangan antara China dengan negara-negara kawasan Asia.

China ternyata merupakan motor terbesar dalam pertumbuhan ekonomi di kawasan ini yang didorong oleh kemampuan perdagangan internasionalnya. Produkproduk China yang masuk ke negara-negara Asia juga menjadi sangat banyak dan bahkan mulai membanjiri pasar lokal. Pertumbuhan pesat perdagangan dunia masih akan terjadi di Asia dengan China sebagai motor utamanya. 


\begin{tabular}{|l|r|}
\hline Global Insigint Journal & Vol 02, No. 01 \\
April-September 2017 \\
ISSN 2541-318X
\end{tabular}

Dengan kebangkitan ekonomi China yang kini telah menjadi kekuatan ekonomi besar, mampu menjadi alat "bargaining position" dalam mempengaruhi hubungan politik dengan beberapa negara di kawasan Asia, seperti yang terjadi dalam sengketa teritorial di Kepulauan Diaoyu antara China dan Jepang. Jepang telah mendapatkan manfaat dari investasi dan ekspor ke China. Dan pertumbuhan ekonomi Jepang membutuhkan pasar China. Sementara itu, investasi Jepang di China juga mendorong tenaga kerja lokal. Dalam hal ini, hubungan Jepang-China tidak dapat dipisahkan, karenanya upaya diplomasi terus diupayakan pemerintah Jepang untuk meredakan ketegangan.

\section{KESIMPULAN}

Sebelum tahun 1978, FDI yang mengalir ke China hampir nol, akan tetapi saat ini China merupakan negara penerima FDI terbesar kedua di dunia setelah Amerika. Diantara negara-negara berkembang, China menampung lebih dari 30 persen aliran FDI dunia yang mengalir ke negara-negara berkembang. Para pakar berpendapat bahwa transformasi ekonomi China yang relatif mulus dan mampu menciptakan ekselerasi perekonomian didukung oleh beberapa faktor, diantaranya adalah karena para pemimpin negara mempunyai kemampuan dan komitmen yang sangat besar untuk melakukan transformasi ekonomi dari planned economy ke market economy, masyarakat dan staf pemerintahan China sudah siap menghadapi sistem ekonomi baru, dan stabilitas politik terjaga selama proses transformasi berjalan.

\section{DAFTAR PUSTAKA}

Backman, Michael, Asia Future Shock. Jakarta: Ufuk Press. 2008.

Chow, Gregory, Memahami Dasyatnya Ekonomi China. Solo: Tiga Serangkai. 2010. 


\begin{tabular}{|l|r|}
\hline Global Insigint Journal & Vol 02, No. 01 \\
April-September 2017 \\
ISSN 2541-318X
\end{tabular}

Deliarnov, M.Sc, Mencakup Berbagai Teori dan Konsep yang Komprehensif; EKONOMI POLITIK, Jakarta: Erlangga, 2006.

Engardio, Pete, Chindia. Jakarta: Gramedia Pustaka. 2008.

Jemadu, Aleksius, Politik Global Dalam Teori dan Praktik, Yogyakarta: Graha Ilmu, 2008.

Mark, N Lam John L. Graham. China Now. Jakarta: Gramedia. 2007.

Masoed, Mohtar, ILMU HUBUNGAN INTERNASIONAL; Disiplin dan Metodelogi, Jakarta: Pustaka LP3ES Indonesia, 1990.

Meredith, Robyn, Menjadi Raksasa Dunia. Bandung: Nuansa, 2010.

Naisbit, John, Dorris Naisbit. China's Megatrends, 8 Pilar Masyarakat Baru. Jakarta: Gramedia Pustaka. 2010.

Rudy, T.May , Studi Strategis dalam transformasi sistem Internasional Pasca Perang dingin, Bandung: Refika Aditama, 2002.

Siregar, T.M, Pembangunan Ekonomi Tiongkok; dari fokus pedesaan ke pasar internasional. Jakarta: Pustaka Pena. 2002.

Wiryawan, Bangkit, A Zona Ekonomi Khusus Strategi China Memanfaatkan Modal Global. Depok: Yayasan CCS. 2008.

Yatsko, Pamela, New Shanghai, Lika-liku Kelahiran Kembali Kota Legendaris di Cina. Batam: Interaksara. 2003. 